\title{
Preliminary Observations on the Behavior of Feral Chickens (Jungle Fowl) on the Island of Kauai Reflections on Domestication as Complexity
}

\author{
Niccolo Caldararo* \\ Department of Anthropology, San Francisco State University, California
}

Submission: August 22, 2017; Published: September 01, 2017

*Corresponding author: Niccolo Caldararo, Department of Anthropology, San Francisco State University, Department of Biology, City College of San Francisco, California

Abstract

Two study sessions of fieldwork on the Hawaiian island of Kauai were undertaken in 2012 and 2014 on the behavior of the feral chickens on the island. The inquiry was directed to understand the nature of social organization given the animals had no natural predators and were largely ignored by the present population. These observations were compared with those of reported captive Jungle Fowl studies and domesticated fowl. Comparisons with other vertebrate populations with out natural predators are considered. Implications for the self-domestication of Homo sapiens are discussed.

Keywords: Avifauna; Gallus gallus; Feral chickens; Social organization; dominance; Sex ratio; Domestication; Complexity

\section{Introduction}

One is startled to find the serene blue vistas, wide beaches and deep green tropical terrain of the island of Kauai disturbed by the crowing of roosters. This is an experience that punctuates and surprises most visitors to the beautiful Hawaiian island of Kauai. Forde [1] believed chickens of Melanesia and Polynesia were derived from the feral chickens of Southern Asia and were recent arrivals. Genetic data seem to support the idea of South Asia as a origin point for Gallus gallus Fumihito [2] Other sources argue that in addition to the chickens brought by the two waves of Polynesians, workers brought to the islands by European property owners in the 19th and 20th century from the Philippines have added to the stock as well as commercial breeds from the US mainland that were freed by destructive storms in the past 4 decades.

A recent study by Gering [3] supports these earlier findings. A comprehensive study of the dispersal of chickens and their use by humans has been produced by Pitt [4]. Some locations on the island have yielded bones of chicken dating from Native Hawaiian occupations of AD 1430-1665 Burney [5]. It appears from recent archaeological finds of chicken bones in South America dated in the early 1400s A.D., that Polynesians somehow brought chickens close enough to the mainland for them to be raised by Inca Lovette [6], Storey [7]. DNA analysis identifies the bones as those of animals possessed by Polynesians at about the same time. The study of domesticated animals was a means by which Darwin [8] came to understand the process of natural selection and it may provide clues as well to the development of social complexity. Most research in domesticated chickens has concentrated on pecking in chicks or on following Klopfer \& Hailman [9]; group stimulation of food consumption Bayer [10], dominance as a means of understanding social organization (the pecking order) Schjelderup-Ebbe [11]. Endocrine studies of behavior variation and changes in physiology as well as aggression have been a focus, especially in the use of varieties for fighting Scott [12].

The nature of the group, if it is stable, has a significant effect on dominance interactions Etkin [13] and the dominance hierarchies are usually linear in A dominates B, B over C et cetera to $\mathrm{Z}$ the lowest in rank or status with also males over females. General surveys of chicken behavior have appeared as in WoodGush [14], but a study of the Jungle Fowl on Kawai has not yet appeared. Kruijt's [15] study is used as a comparison to my observations. It is of interest to this study that Kruijt [15] raised a number of Jungle Fowl in captivity as a control for his field observations, though his focus was on the ontogeny of behavior in relation to instinct, this check provides a useful background. He had obtained his animals from a supplier of birds and 
their physiology indicated some degree of interbreeding with domestic fowl. This brief note will hopefully lead to a more comprehensive study in Kawai.

\section{Observation}

\section{Sex Ratio and Vocalizations}

One of the initial characteristics of the Kauai Gallus gallus noted by the author was the low sex ratio of male to female adults. As the first year field study was limited no data was collected but in the second year data collection verified a definite low number of females to males on the island. Other studies have found increased numbers of males produced by feral and healthier females than those captive and of a less robust health condition Parker 2002.

This contrasts with captive Gallus gallus populations in general. A second general characteristic noted in the initial study period was crowing produced at a variety of times of the day and night differing significantly from the periods of crowing most often experienced by the author with domestic fowl. Kruijt [15] describes "crowing" in a developmental context but does not report the frequency of crowing in social interaction. Collias [16] has noted three basic calls produced by captive red jungle fowl in a San Diego Zoo context. Two of these calls (loud "harsh" threat calls of low frequency while loud "harsh" calls of high frequency were deemed alarm calls) seemed to correspond to those noted most often by males in Kauai. Associating either with typical domestic calls was not possible given the conditions of the study.

As Red Jungle Fowl are considered the ancestral stock from which domestic varieties have evolved Crawford [17] comparisons seem apt. A major difference noted between the behavior of Red Jungle Fowl in a wild environment was a general "wary" response to the presence of humans. This could be interpreted as the result of predation by humans and other vertebrates Collias and Collias [18] Collias and Saichuae [16]. Gering [3], recordings suggest hybrid effects on vocalizations, but their results do not inform us as to timing of calls or associations with humans or other vetebrates.

Another characteristic of the Kauai chickens that differed from behavior seen in domestic chickens in the mainland (California) was the association of males with small numbers of females, from one to four usually. This too was observed by Collias and Collias [18] and Collias and Saichuae [16]. Sex ratio of domestic fowl seem to be found by some researchers to be produced in equal numbers on birth but with a high number of female deaths shortly after Feng [19]. Domestic roosters might number 1 to 10 or 20 depending on the means and plan of the owner for production while some specific breeders who are interested in unusual traits sought after by aficionados, might have almost equal numbers in their pens.

On Kauai I found the sex ratio of adults to vary from 1:1 to as many as 1:5 with some males appearing to possess no females. The effort of these to consort with another rooster's females often resulted in "crowing." I did also appear that the same male could be found with more females associated with him at different times of the day, though those females with chicks seemed to attract the attention of their males more often. Male alliances against peripheral males were also noticed. It was often hard to count the number of females associated with certain males at every moment as females and chicks often spent time under the leaves of clusters of vegetation.

Males could be periodically found also in these clusters and if disturbed might "crow" though I could not discern if this was uniquely an alarm call or an announcement associated with dominance. There were few aggressive encounters noted among males, but males often chased females, yet rarely pecked them. I assumed that local feral cats were predators of the chickens but local Hawaiians and other residents argued this was not possible. I did observe local cats on two occasions near chickens and in each case the cats acted quite furtive as if scared and did not stalk either adults or chicks. Native Hawaiians I spoke to noted that the cats were afraid of the roosters. I suggested that the roosters might be "crowing" at night due to the threat of cats hunting but they seemed amused at the thought.

I also attempted to find the source of rooster calls at night especially between $1 \mathrm{AM}$ and $3 \mathrm{AM}$ but could never identify a focus. While I cannot make any statements about specific animals as I did not have time to attempt to label specific ones, nor was I able to identify them effectively so as to recognize them with sufficient reliability (except two, one male who I called "White tail" and a female who was so plump she stood out from every crowd). "Crowing" is a signal which I cannot discern from the discussions of Collias [20], but I will confine myself to simply note the vocalizations most often heard during my research from males. These probably included both threat and warning or alarm calls identified by Collias [20]. My experience with domestic fowl in California identifies two times of calls by male fowl, during the night what attacked by fox, coyotes, racoons or rodents (probably similar to Collias' alarm call. The second period would be in the early morning between 5 am and about 7 or $8 \mathrm{am}$. The roosters of Kauai, however, have a very different period of calling. It is clearly not uniform like domesticated animals.

Rather I found that "crowing" can start as early as 1:30 AM with one rooster beginning and others chiming in, and rounds of "crowing" continue. Over several days in early January 2014 in the town of Kapa'a I found that "crowing" bouts would come to cluster around 3AM to 5AM only to resurge around 6AM to 7AM. Short bursts of "crowing" might be heard throughout the day seemingly in association with defense of hens or encroachment by subordinate or foreign roosters. These, however, were seldom followed by chiming in bouts. And such calls fall off in number after about $4 \mathrm{pm}$ until again the middle of the night.

Behavior at night was impossible to chart as I lacked night vision equipment, yet the use of cover by the animals, both 
male and female and chicks was continuous throughout the day, especially given any close human, other mammal or other birds present. Some small birds seemed to be generally ignored, but adult sea gulls were a definite source of avoidance. Escape running as described by Kruijt [15] was observed nearly continuously by chicks followed in frequency by hens and then adult males. Alert postures described by Kruijt (1964) as well as the vocalizations of chicks were also consistent with those I heard in Kawai. Chicks appeared to run when loud noises occurred, mammals or other birds approached. I did not seem what I would describe as "chick clustering" as Kruijt [15] records.

\section{Agonistic Behavior}

Chasing, "crowing" and wing flapping were all observed in the study population and have been described by other researchers Johnson, Zuk \& Fessler [21]. All three behaviors were observed with rather equal frequency but generally increased in the presence of tourist feeding. Avoidance of humans was somewhat uniform in all birds encountered on the island. The amount of fear expressed and human avoidance has been shown to vary given different conditions of Red Jungle Fowl rearing and so it would seem likely that a more detailed study in different parts of the island might result significant variations as reported by Hakansson, Bratt \& Jensen (2006). Aggressive displays and actual agonistic contact of males was rarely observed, certainly much less than noted by Kruijt [15] but that is mostly like due to the captive conditions of his study. Kruijt [15] notes "crowing" in males after injection with testosterone. The birds seemed to avoid dogs, but as all dogs seen were either on leases or tethered the extent of the interaction of the two species was unclear. Cats, as mentioned, appeared fearful when in areas of the Red Jungle Fowl, but it was unclear if they were fearful of the humans who were also present or of the birds. The interaction of rats and fowl could also not be discovered and night calling may have been related to the activities of nocturnal rat acitivity. A Limahuli Garden volunteer suggested that in her experience and that of other Park personnel, cats at the Garden only attacked rodents but there was no way of confirming this as there were no studies done and no supporting evidence as night infrared video.

\section{Groupings}

Two separate groups seemed to dominate the area of the near beach in Kapa'a where I concentrated my observations. A typical morning found the following numbers of the two:

\section{A. Group with "White Tail”}

Males 4 juveniles or chicks 4 Females 2

Group without "White Tail”

\section{B. Males 3 juveniles and chicks 0 Females 4}

As group an approaches group B one male in A "crows" no reply. Usually members of the two groups "crow" in response to each other.
As group an approaches group B one male in A "crows" no reply. Usually members of the two groups "crow" in response to each other (Table 1).

Table 1: Group membership and number seems to change throughout the day.

\begin{tabular}{|c|c|c|c|}
\hline 7AM & Males & chicks & Females \\
\hline A & 2 & 0 & 4 \\
\hline B & 3 & 0 & 5 \\
\hline 8AM & & & \\
\hline Mixed A \& B 4 & & 0 & 5 \\
\hline 9AM & & & \\
\hline A & 1 & 0 & 3 \\
\hline NOON & & & \\
\hline$?$ & 2 & 0 & 2 \\
\hline
\end{tabular}

After 3 PM numbers fell off significantly to one male or one female on most days. Since I was not able to identify specific animals with certainty group membership is only suggested here. Some feeding occurred both by local people and tourists so the specific nature of time distribution could be skewed by this interference. I could not quantify such a relationship, but the presence of the birds in this locality might be affected by human presence.

\section{Conclusion}

The study of any animal is of interest to widen our understanding of behavior and social complexity and their affects on environment and health. What is of most interest to a study of human evolution is the possibility of studying what is unique in human behavior and especially of an animal that has no natural predators. Studies of comparative animal physiology and psychology allow us to understand what is unique to humans and I have produced several investigations on this subject Caldararo [4-6]. Here with our Red Jungle Fowl on Kauai we have such a laboratory experiment and the contrast with domestic chickens allows us to make some conjectures related to domestication and behavior [22-24].

Most studies of populations without predators focus on population density of the prey animal or effects on the ecology Hoverman \& Relyea [25], my interest is certainly focused on these points as humans are expanding their population tremendously due to a lack of predators and internal controls. Future research must be directed to other aspects of the Red Jungle Fowl and its lack of predators. It is obvious that humans have spent the majority of the time since they appeared as a genus (approximately 2 mya as Homo habilis, for example) or as a species (early Homo sapiens in Africa at about 200,000 B.P.), as simply food gatherers most of our behavior can be compared positively with other primates of today. Given that some birds (like crows) make tools, the manufacture of tools alone is not all that significant. Perhaps the most significant behavior we express is the control of fire, which is only reasonably established without question at about 400,000 B.P. Caldararo [26]. 
It is only after about 10,000 years ago that we began to produce sedentary communities and become food producers instead of food collectors. Since ants also are food producers (farm fungus and raise aphids, see Forel [27]; Holldobler \& Wilson [28] perhaps that transition is not so important. What is unique is the way humans have exterminated all the animals that preyed on them. In addition to being food producers we have achieved the status of dominant predator a position that is unlikely to have been achieved by any other animal in the history of the planet. It is perhaps the combination of these two achievements, food production and elimination of predators, that has given humans such a dominant position, given that other traits that seem unique, food sharing, building structures and cooperation in complex societies are traits we share with some ant species.

The problem of the effects of domestication on behavior is of interest as we have learned in the past decade that domesticated animals have reduced brain size and brain regions compared to wild animals of the same species Kruska [29]. This problem is of importance, as it relates to the domestication of ourselves Wilson [30]. The contrast of the Red Jungle Fowl of Kauai with domestic chickens is dramatic and perhaps as much as the contrast of domesticated humans of today's global societies and those of hunter-gatherer societies 10,000 years ago and more. I investigate this further in my recent book Caldararo [31]. A recent paper combines the effects of disease and complex social life in a comparative study Caldararo $[32,33]$.

\section{Acknowledgement}

A draft of this paper appeared on the Social Science Research Network website in January of 2015.

\section{References}

1. Forde, Daryl C (1949) Habitat, Economy and Society, 1963 paperback edition, New York EP Dutton \& Co.

2. Fumihito, Akishinonomiya, Tetsuo Miyake, Shin-Ichiro Sumi, Masaru Takada, et al. (1994) "One Subspecies of the Red Junglefowl (Gallus gallus gallus) Suffices as the Matriarchic Ancestor of all Domestic Breeds." Proceedings of the National Academy of Sciences of the United States of America 91(26): 12505-12509.

3. Gering E, Johnsson M, Willis P, Getty T, Wright D (2015) Mixed ancestry and admixture in Kauai's feral chickens: invasion of domestic genes into ancient Red junglefowl reservoirs. Mol 24(9): 2112-2124.

4. Pitt J, Gillingham PK, Maltby M, Stewart JR (2016) New perspectives on the ecology of early domestic fowl: an interdisciplinary approach. J of Arch Sci $74: 1-10$

5. Burney David A, Helen F James, Lida Pigott Burney, Storrs L Olson, et al. (2001) Fossil Evidence for a Diverse Biota from Kaua'i and Its Transformation since Human Arrival. Ecological Monographs 71(4): 615-641.

6. Lovette, Irby (2008) How did the chicken cross the sea. Living Bird, Sciencescope, Cornel University 22-23.

7. Storey AA, JM Ramírez, D Quiroz, DV Burley, DJ Addison, et al. (2007) Radiocarbon and DNA evidence for a pre-Columbian introduction of Polynesian chickens to Chile. Proceedings of the National Academy of Sciences USA 104(25): 10335-10339.
8. Darwin Charles (1868) The Variation of Animals and Plants Under Domestication, London, UK.

9. Klopfer, Peter H, Hailman, Jack P (1967) An Introduction to Animal Behavior, Englewood Cliffs, Prentice-Hall Biological Science Series.

10. Bayer E (1929) Beitrage zur Zeeikomponenten-theorie des hungers. Zeit F Psych 112: 1-54.

11. Schjelderup Ebbe T (1922) Beitrage zur Sozial-psychologie des Haushuhns. Zeit f Psyuch 88: 225-252.

12. Scott, John Paul (1963) Animal Behavior, New York, Doubleday Anchor for the American Museum of Natural History, edition.

13. Etkin, William (1964) Social Behavior and Organization Among Vertebrates, Chicago, University of Chicago Press.

14. Wood-Gush (1955) The behaviour of the domestic chicken: A review of the literature. Review Article, British Journal of Animal Behavior 3(3): 81-124

15. Kruijt JP (1964) Ontogeny of Social Behaviour in Burmese Red Junglefowl (Gallus Gallus Spadiceus) Bonnaterre. Behaviour Supplement No. 12, Ontogeny of Social Behaviour in Burmese Red Junglefowl (Gallus gallus spadiceus) Bonnaterre pp. (1-10): 1-201.

16. Collias NE, P Saichuae (1967) Ecology of the Red Jungle Fowl inThailand and Malaya with reference to the origin of domestication. Nat Hist Bull Siam Soc 22: 189-209.

17. Crawford RD (1984) Domestic fowl in I L Mason, ed, Evolution of Domesticated Animals, Longman, London,UK.

18. Collias NE, EC Collias (1967) A field study of the Red Jungle Fowl in North-central India. Condor, 69(4): 360-386.

19. Feng, Yan-ping, Yan-zhang Gong, Nabeel Ahmed Affara, Xiu-li Peng, Jinfeng Yuan, et al. (2006) Analysis of the Offspring Sex Ratio of Chicken by Using Molecular Sexing. Agricultural Sciences in China 5(7): 545549.

20. Collias, Nicholas E (1987) The Vocal Repertoire of the Red Jungle fowl: A Spectrographic Classification and the Code of Communication. The Condor 89(3): 510-524

21. Johnsen, Torgeir S, Zuk Marlene, Fessler Elizabeth A (2001) Social dominance, male behavior and mating in mixed-sex flocks of Red Jungle Fowl. Behaviour Jan 138(1): 1-18.

22. Caldararo NL (2005) Hair Human Evolution, and the Idea of Human Uniqueness. Evolutionary Anthropology 14: 132-133.

23. Caldararo NL (2009) The tendency to make man an exception. in Ed: Emil Potocki and Juliusz Krasinski, Primatology: Theories. Methods and Research. pp. 113-128.

24. Caldararo NL (2012) Complex Animal Societies, Domestication and Human Uniqueness. J Primatology 1: 103-116.

25. Hoverman Jason, Relyea Rick A (2012) Long term impacts of predators on prey: inducible defenses. population dynamics and indirect effects. Oikos 121 (8): 1219-1230.

26. Caldararo NL (2002) Human ecological intervention and the role of forest fires in human ecology. Sci Total Environ 292(3): 141-65.

27. Forel, Auguste (1929) The Social World of the Ants: Compared with that of Man. New York, USA.

28. Holldobler Bert, Wilson EO (1990) The Ants, Cambridge, Belknap Press.

29. Kruska DCT (2007) The effects of domestication on brain size. in Jon Kaas ed., Evolution of Nervous Systems, New York, Academic Press 3(11): 143-153. 
30. Wilson Peter J (1988) The Domestication of the Human Species. New Haven, Yale University Press.

31. Caldararo NL (2014) The Anthropology of Complex Economic Systems: Inequality, Stability and Cycles of Crisis, Lanham, Lexington Press.

32. Caldararo NL (2015) Social Behavior and the Superorganism:
Implications for Disease and Stability in Complex Animal Societies and Colony Collapse Disorder in Honeybees. INDECS 13: 1-10.

33. Hakansson J Bratt, C Jenson P (2007) Behavioural differences between two captive populations of red jungle fowl (Gallus gallus) with different genetic background, raised under identical conditions. Applied Animal Behaviour Science 102(1-2): 24-38.

\section{Your next submission with Juniper Publishers will reach you the below assets}

- Quality Editorial service

- Swift Peer Review

- Reprints availability

- E-prints Service

- Manuscript Podcast for convenient understanding

- Global attainment for your research

- Manuscript accessibility in different formats

( Pdf, E-pub, Full Text, Audio)

- Unceasing customer service

Track the below URL for one-step submission https://juniperpublishers.com/online-submission.php 